\title{
Gender and Migration
}

\author{
by Caroline B. Brettel \\ Cambridge, MA: Polity Press, 2016 \\ Immigration \& Society Series \\ ISBN 978-0-7456-8789-6 \\ Softcover $\$ 27.95,240 \mathrm{pp}$.
}

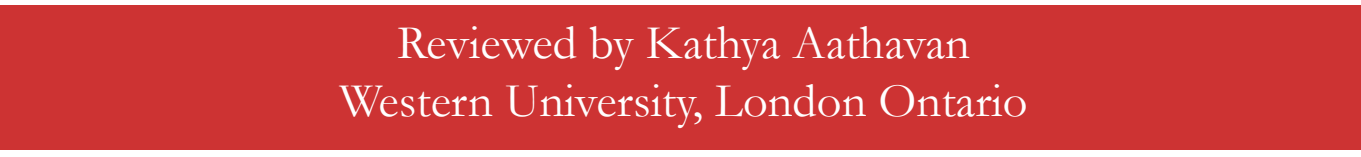

Gender has been absent as a subject of analysis within migration literature in the past, and research on how gender shapes pre- and post-migration conditions has been missing. However, in the last few decades, gender and its relationship to migration has gained momentum in scholarly research. In the book Gender and Migration, Caroline B. Brettel synthesizes the complex and segmented research, both quantitative and qualitative, on the effects of gender in the processes and consequences of migration, primarily in the post-war American context. According to Brettel, women became visible in the migration literature about three decades ago, and in this time, research went from the "just add women" approach that examined female migrants descriptively into a more theoretical approach of gender in general. Along these lines, the author contests early research that examined the effects of gender as a dichotomous and stagnant variable on migration. Instead, she is interested in the dynamic nature of gender as it affects the migration experience, and as it is redefined and renegotiated in the process of migration through gendered institutions such as the state, the family, and the labour market.

Brettel brings gender to the center stage in this book by considering it a constitutive element of migration. The book examines the gendered nature of the structures and institutions that dictate the process of migration and the ways in which gendered relations are maintained, challenged, and redefined in and through this process. It also explores the intersections of gender with race and class. True to feminist literature, Brettel allows space for agency to enact change within the constraints placed by macro-level structures at the global, national, and community level. A welcome addition to this complex and dynamic relationship would be a more nuanced examination of gender and sexuality beyond the conventional norms of binary identity and heteronormativity. The author writes that this is an area that needs further investigation with migration literature.

In chapter one, Brettel dives into the historical patterns of the gendered demography of migration. She is interested in the gendered compositions of migration routes and the transitions of these compositions through time. For a nuanced understanding, she turns to Gabaccia and Zanoni's typology of gendered migrations, which quantifies streams into heavily male dominant, male predominant, gender balanced, female predominant and heavily female dominant (2012). She looks at United States immigration history from the mid-nineteenth century to the present, to identify transitions in the gendered streams and the reasons behind them. For example, of the 3.5 million immigrants in the US from the West Indies in 2009, over half were women, making 
this a predominantly female-oriented stream. This can be explained by the local gender ideologies particularly of Trinidad and Tobago, the Dominican Republic, and Jamaica, where female-headed households made it common for women to be breadwinners; as well, the demand in the US for domestic labour and nurses made it easier for women to obtain labour certificates for migration in comparison to their male counterparts. Brettel is critical of the claim in earlier migration literature that global migration routes have feminized since the 1960s. And by synthesizing available research, she examines whether this feminization can be noted in the migration streams coming into the US. In this process, the book produces a gendered US migration history spanning from the spur of emigration of young single Irish women escaping the Potato Famine in the 1800s to the Indian men of the Imperial Valley of California who married Mexican women, and the refugee streams coming out of Asia and Africa.

In the next chapter, the book highlights how this composition explored previously is affected by the gendered biases and expectations within the seemingly gender-neutral immigration laws and policies. This section also examines the ways in which legal structures affect the experience in the host country differentially along the gender lines. This follows the discussion from the earlier chapter, as migration laws and policy are a primary factor in the gendered nature of migration streams and their transitions. In the case of Chinese migrantsthis includes labour demands which called for large proportions of young male labourers to migrate to the US. However, in the guise of anti-prostitution laws that "save" Chinese women from being victimized and "protect" White men from contracting diseases that spread through prostitution, family reunification was not allowed, and Chinese women were restricted from entering the country. In this way, a "bachelor society" was created (p. 39). As illustrated through this example, this chapter examines the laws determining the construction of migration streams and its implications for immigrant groups. But more importantly, Brettel explores the larger politics around the changes in the laws and the how they are reasoned and justified. Moreover, the book also explores the differences in political participation between the genders. She finds that immigrant women are more likely to be involved in the community, which signals integration, and encourages future research on the ways that women participate in politics.

In chapter three, the book explores the role played by the economic environment of both the host country and the sending country on the gendered nature of migration. The shifting global labour demands, as well as the labour market characteristics of the countries involved, play a vital role in the gendered nature of mobility. Often, it is the primary reason of migration, and a primary indicator of integration in the host country; however, Brettel concentrates on the ways in which gender shapes and is shaped in this process. The labour markets in both sending and receiving countries are segmented by gender as well as race and class. Responding to global shortages in certain fields like information technology, workers from India and China or health care workers from Philippines, India, and the Caribbean participate in the skilled labour market and are able to navigate the migration experience better than those whose skills are not in demand and thus get channeled into immigrant occupational niches as well as temporary or precarious work. In this chapter, Brettel also explores global care work, sex trafficking, and immigrant self-employment.

In the final chapter, the author examines gender and the immigrant family, and how gender roles and relations are redefined and renegotiated within the context of migration. She challenges the notion that migration is innately empowering for the women in immigrant families. In some cases, increased economic independence in the host country does lead to increased autonomy and freedom for women. However, in other cases instability, poverty, and hardship experienced in the post-migration context make women wishful for the life they had back at home. Moreover, past research has found that for some women, the process of migration is disempowering. Literature on 
Somalian migrant women in New York, for example, states that gender relations become strained because of the structural barriers that lead to persistent unemployment of the men, and the preference of welfare assistance programs for women. Men feel emasculated by the system and the host community, and this negatively affects the autonomy and freedom of women in both the private and public sphere. In this chapter, Brettel also illustrates the ways in which gender norms and relations are renegotiated by individuals, immigrant groups, and their home communities. In the example of a female breadwinner, the meaning of motherhood is redefined to include providing for the family economically rather than just through emotional labour within the home. This affects the gender relations within the home, as well as the gender norms and expectations within the community.

With the use of demographic research on general migration patterns, and the synthesis of hundreds of localized examples of men and women migrating to the US from all over the globe at different points in time, this book is able to depict how "gender shapes the reality of migration" (p. 172). Going forward, the author calls for more research on gendered differences in political participation, immigrant health, intersections of gender, sexuality and migration, and second-generation immigrations. Migration is at the forefront of discussion now in politics and policy, the media, and academia, with increasing proportions of the world's population being displaced as well as highly mobile. Gender and Migration can provide an accessible and well-executed overview of the topic in its complexities for undergraduate students, academics, and anyone interested in an introduction migration studies.

\section{Reference}

Gabaccia, D., and E. Zanoni. 2012. Transitions in gender ratios among international migrants, 1820-1930. Social Science History 36(2):197-221. 